ISRNTI 67.07.29

\author{
${ }^{1 *}$ Kudaibergenov S.E., ${ }^{1}$ Ismagambetova Z.N, ${ }^{2}$ Abirova B.I. \\ ${ }^{1}$ Al-Farabi Kazakh National University, Kazakhstan, Almaty \\ ${ }^{2}$ Kazakh University Ways of Communications, Kazakhstan, Almaty \\ *e-mail: uly-juz-kanly@mail.ru
}

\title{
ARCHITECTURAL IMPORTANCE OF THE AHMED YASSAWI MEMORIAL-COMPLEX
}

In this article, the authors define the place and significance of Ahmed Yassawi as a colorful figure in the Turkic world. The article defines the cultural significance of Ahmed Yassawi's role in the Sufi worldview formation, the influence of Sufism on the spiritual and aesthetic culture of the Central Asia Turkic peoples in the Middle Ages. The religious creativity of Ahmed Yassawi undoubtedly had a spiritual impact on the worldview of the Turkic people of Central Asia, changing their worldview and understanding of the place and purpose of a person in their life. Under the influence of Yassawi and other Sufi thinkers, Central Asia turns into a center of divinely inspired intuition during the Middle Ages. The city of Turkestan in this period becomes the epicenter of a new spiritual practice, which opened the way for a person not only personal liberation from suffering, but also proposed a new strategy of overcoming the life hardships through personal choice. The authors of this article determine the architectural significance of the memorial complex dedicated to Ahmed Yassawi's memory. Assessing the mastery of medieval architects, the authors draw attention to the innovation of medieval Central Asian architects. This is an architectural achievement of that distant era: blue and white ceramics, which was embodied in the construction of the Ahmed Yassawi's mausoleum. Careful attitude to the cultural heritage of the Central Asia steppe civilization is one of the most important tasks of the "Ruhani zhangyru" (Spiritual revival) national program. This will allow educating the public tradition of careful attitude and respect for the spiritual heritage of the past, for the rich culture of Kazakhstan.

Key words: Ahmed Yassawi, memorial, tombstone, pilgrimage, mauzoleum.

\author{
${ }^{1 *}$ Құайбергенов С.Е., ${ }^{1}$ Исмағамбетова 3.Н. ${ }^{2}$ Абирова Б.И. \\ 'әл-Фараби атындағы Қазақ ұлттық университеті, Қазақстан, Алматы қ., \\ ${ }^{2}$ Қазақ, қатынас жолдары университеті, Қазақстан, Алматы қ., "e-mail: uly-juz-kanly@mail.ru
}

Ахмет Яссауи мемориалдық кешенінің сәулеттік маңыздылығы

Бұл мақалада авторлар А. Яссауидің түркі әлеміндегі әсем тұлға ретінде орны мен маңыздымығын көрсетеді. Мақалада А. Яссауидің суфизм дүниетанымын қалыптастырудағы рөлі, суфизмнің орта ғасырдағы Орта Азияның түркі халықтарының рухани және эстетикалық мәдениетіне әсері анықталады. А. Яссауидің діни шығармашылығы, әрине, Орталық Азиядағы Түріктердің дүниетанымдық көзқарасына рухани әсер етті, олардың көзқарастарын өзгертіп, адам өмірінің орны мен мақсатын түсінді. Яссауи мен басқа да суфийлердің ықпалымен Орталық Азия орта ғасырлар бойы Құдайдың рухымен рухтандырылған түйсігі орталығына айналады. Осы кезеңде Түркістан қаласы адамның тек қана қиындықтан құтылуға жол ашып, жеке таңдау арқылы өмірдегі қиындықтарды еңсерудің жаңа стратегиясын ұсынған рухани тәжірибенің эпицентріне айна^ды. Мақаланың авторлары Ахмет Яссауи еске алуға арналған мемориалдық, кешеннің сәулеттік маңыздымығын анықтайды. Ортағасырлық сәулетшілердің білімдерін бағалай отырып, авторлар ортағасырмық орталықазиялық сәулетшілердің инновацияларына назар аударады. Бұл ерте заманның сәулеттік жетістігі - «Ахмет Яссауи кесенесінің құрылысында бейнеленген көк және ақ керамика». Орта Азияның дала өркениетінің мәдени мұрасына бейжай қарамау «Рухани жаңғыру» бағдарламасының маңызды міндеттерінің бірі болып табылады. Бұл халықты өткеннің рухани мұрасына, Қазақстанның бай мәдениетіне құрметпен қарау дәстүріне тәрбиелеуге мүмкіндік береді.

Түйін сөздер: Ахмед Яссауи, мемориал, құлпытас, қажылық, кесене. 


\author{
${ }^{1 *}$ Кудайбергенов С.Е., ' Исмағамбетова З.Н., ${ }^{2}$ Абирова Б.И. \\ 'Казахский национальный университет имени аль-Фараби, Казахстан, г. Алматы, \\ ${ }^{2}$ Казахский университет путей сообщений \\ Казахстан, г. Алматы, *e-mail: uly-juz-kanly@mail.ru
}

\title{
Архитектурное значение мемориального комплекса Ахмета Яссави
}

\begin{abstract}
В данной статье авторы определяют место и значимость А. Яссауи как колоритной фигуры в тюркском мире. В статье Аается определение культурной значимости роли А. Яссауи в формировании суфийского мировоззрения, влияние суфизма на Ауховную и эстетическую культуру тюркских народов Центральной Азии в период средневековья. Религиозное творчество А. Яссауи оказало без сомнения духовное воздействие на мировоззрение тюрков Центральной Азии, изменив их мироотношение и понимание места и назначения человека на жизненном пути. Под влиянием Яссауи и других суфийских мыслителей Центральная Азия превращается в периоА средневекововья в центр боговдохновенной интуиции. Город Туркестан в этот период становится эпицентром новой Ауховной практики, открывшей переА человеком путь не только мичного освобождения от страданий, но и преАложил новую стратегию - преодоление жизненных невзгод путем личного выбора. Авторы данной статьи определяют архитектурную значимость мемориального комплекса, посвященную памяти Ахмета Яссауи. Оценивая мастерство средневековых зодчих, авторы обращают внимание на новшество средневековых центра^ьно-азиатских зодчих. Это архитектурное достижение той далекой эпохи - «бело-голубая керамика, которая нашла воплощение в построении мавзолея Ахмета Яссауи. Бережное отношение к культурному наследию степной цивилизации Центральной Азии - одна из важных задач программы «Рухани жангыры». Это позволит воспитывать общесто в традиции уважения и бережного отношения к Ауховному наследию прошлого, к богатой культуре Казахстана.
\end{abstract}

Кмючевые слова: АхмеА Яссауи, мемориал, надгробие, паломничество, мавзолей.

\section{Introduction}

The relevance of the chosen topic of the scientific article, the study of the work of Ahmed Yassawi in textual terms allows to reveal its popularity, general significance and relevance for all Turkic peoples and in different historical eras. This tradition has resumed in recent decades. Thus, in the city of Turkestan and Almaty, the texts of "Divani-hikmat" were published in the modern Kazakh language.

Traditions and life, the culture of our people are associated with cultural heritage. It has a very important moral, patriotic value for the people of Kazakhstan. Objects such as the Khoja Ahmed Yassawi mausoleum, objects of the Altai Territory, Southern and Western Kazakhstan are now known not only in Kazakhstan and throughout the world. Therefore, the President set one of the six main tasks to create a historical, Kazakhstani belt of cultural heritage.

Yassawi is the founder of the "Turkic" way (tariqa) of the mystical knowledge of Allah in Islam. Recognizing the importance of his ideas about the single essence of all being, about closeness and even the identity of the process of knowing God by self-awareness, about the need for their own spiritual experience on the path of contemplation, communication, connection with God, the researchers note the adaptation of these ideas to the people's world outlook. But besides all the above,
Yassawi entered the history of spiritual culture from the point of view of participation in the process of Arab-Persian-Turkic language interaction as a great master of artistic expression, understandable and close to the common people.

Sufism in the Islamic world is a spiritual culture that performs the complex function of translating basic traditions, values, ideological orientations, which change under the influence of the dominant factors of Islamic culture - the Arabic language and religion. On the one hand, Sufism adapts new values to the basic ones, transforming their external form, changing the meanings of the previous patterns. On the other hand, in fulfilling the missionary, apologetic function, Sufism adapts the ideological guidelines of non-Arab peoples to Islam, offering a compromise solution to a number of complex ideological problems. At the same time, it performs the function of preserving ethnic memory. This explains the fact that Sufism was most prevalent in Central Asia, where Islam is accepted and a new reality is created - the world of Islamic culture.

President Nursultan Nazarbayev, arguing about the role of Islam in society, notes that "it is time to look for religion not to oppose people to each other, but to unite the beginnings". It is known from history that the name of A.Yassawi is connected not only with the beginning of Islamization of the Turkic peoples, but also with the process of mutual influence and mutual enrichment of the Tengrian 
and Muslim cultures. Therefore, we can safely say that the teachings of Yassawi played an important role in the development of Islam in our country and in the region as a whole.

The new religious building, named after the great teacher Khoja Ahmed Yassawi, is a visible symbol of the continuity of the spiritual traditions of our people.

The mausoleum of Ahmed Yassawi is an architectural complex that combines the functions of a mausoleum, a mosque, a khanaka (premises for performing mass ritual rites - Kazandyk), administrative and economic premises. The externally symmetric, compact plan includes up to 35 rooms connected by transitions, staircases and corridors that depart from the corners of Kazandyk and divide the room into eight compartmentsblocks. The division of the building into blocks indicates a desire to ensure their independent draught. The builders of different weight structures built on different depth designs.

\section{Research methods}

Research methods are determined by the specificity of the subject of the tasks. The research method was used as the main one. In work other methods of research are applied: system analysis.

\section{Main part}

The mauzoleum of Kozha Ahmad Yasawi is located in the city of Turkestan in the South Kazakhstan oblast of the Republic of Kazakhstan. This unique architectural structure has been included in the World Heritage List of UNESCO. The majestic silhouette of the building can be seen ten kilometers from the city. The splendor and magnificence of the principle mausoleum of Turkestan has staggered and continues to startle pilgrims and tourists.

Many pages of the works of scholars, geographers, travelers, eastern specialists, archaeologists and architects have been dedicated to the biography of Kozha Ahmad Yasawi and similarly to descriptions of his mausoleum. In the Kazakh epos Alpamis batir there is line which communicates the vast size of the structure: «the dome of the Hazrat can be seen in the distance as daylight passess» (Smagulov E., Tuyaqbaev M., 1998).

Mir-Salih Bekhurin the translator of the Governor-General of Orenburg, NA Kryzhanovskii, gave the following appraisal of the monument in 1928 and devoted two special works to the mausoleum, remarked: «by plan and design the powerful creation of the mausoleum has no equal in Central Asia. It is unique» (Prozorov S.M., 2003).
The structure is often called an architectural mausoleum-complex. The architects managed to unite, as a whole and in one complex, 34 various rooms (Jarmuhameduly M., 1999).

The common height of the buildings reaches 39 m., which corresponds to the height oh a modern ten-story building. One of the foremost experts on the medieval architecture of Central Asia, and the chief curator of the restoration of the mausoleum of Khoja Ahmad Yasawi in 1951-1959, L. Yu. Mankovskaya, called it a veritable city monuments (Deweese D., 1999)

Iti is not only the architecture of the monument that is unique. An entire range of the masters of the $14^{\text {th }}-15^{\text {th }}$ centuries is preserved within it: an enormous bronze cauldron, bronze lamps, a banner with a bronze ornamented pommel and engraved doors. It is notable even in the history of the of Turkestan, on whose territory, in addition to the mausoleum of Koja Ahmad Yasawi, exist an entire range of archaeological monuments and medieval architecture.

On the ancient history of the city of Turkestan and its surroundings

Since 1982, the mausoleum of Arystan Baba has been under state protection. It is one of the greatest cultural heritage sites in the country.

Construction of the mausoleum of Khoja Ahmed Yasawi was carried out in the period from 1385 to 1405 , and the architectural monument was erected at the behest of Emir Timur (Tamerlane) in honor of the famous Sufi (ancient Turkic) poet and preacher Ahmed Yasawi on the site where previously there was his modest tombstone. On the site of the old and dilapidated tombstone began construction of a new mausoleum, there Tamerlane celebrated his victory over the Khan Tokhtamysh, the ruler of The Golden Horde. The construction of the mausoleum on the grave of an authoritative Muslim man is a competent political step: thus Tamerlane strengthened its authority among the nomadic peoples. It is believed that he was directly involved in the drafting of the mausoleum and its decoration. During the construction of the mausoleum, innovative architectural solutions were used, which were later used in the construction of Samarkand, the capital of the Empire.

Turkestan is historically the city of Yassy or, as it is called now, the second Mecca for Muslims. Around the sacred grave began to form a necropolis, which included the mausoleums of Rabigha-Sultan Begim, Esim Khan and others. Also, buildings are preserved associated with the Sufi rituals. 
In addition, there are other shrines in close proximity to Turkestan - the "Aisha-Bibi" and "Babadzha Khatun" mausoleums in Taraz, the "Arystan Bab" mausoleum in Otrar. All these historical sites - monuments of architecture and sacred sites - entered the popular route, which gave rise to the belief that "three Hajj to Turkestan are equal to the small Hajj to Mecca", and even in many tourist booklets called "Small Hajj to Turkestan".

Archaeological research on the territory of the Turkestan oasis, delimited in the north-east by the Qaratau mountain range and the south-west by the Sir Dariya, shows that it was inhabited in deep antiquity. Monuments of the Paleolithic era, dated to more than 500,000 years, were discoverednot far from the city of Turkestan. Accidental finds and the field work of archaeologists show that the area of Turkestan was settled in the Bronze Age by bearers of the Andronov culture.

In the Iron Age the region of the middle SirDarya, to which the Turkestan oasis belongs, was settled by tribes which in Archaemenidhistorical sources are called «Saka» (Scythins) and in the Avesta, «Tura. «The area settled by tribes which in Archaemenid historical sources bearing the general name «Tura» has been designated «Turan» in scientific works

The famous historian of the $17^{\text {th }}$ century, Mahmud ibn Wali, in the work Bahr al-asrar fi managib al-akhyar, remarked: «Turkestan is the ancient city of Saksi, which the population is calling Yasi (Hazini, 1995).

Arheological research allows us to locate the older settlement of Yasi on the site of the ancient settlement on Kul-tobe, which is located in the center of the city, $300 \mathrm{~km}$ to the south of the mausoleum of Koja Ahmad Yasawi. The ancient toponym Yasi/ Saksi is probably releated to the names of the ancient inhabitants of the region. In the surrounding area the ancient settlements of Sidaq, Shoy-tobe, Tortkul 1, Tortkul 2 and other monuments were uncovered.

In the $6^{\text {th }}-7^{\text {th }}$ centures the Turkestan oasis was incorporated into the structure of the Turk Khaghanate. In the $8^{\text {th }}$ century, the South of Kazakhstan was absorbed by the Arab Caliphate (632-1258). In the $9^{\text {th }}-10^{\text {th }}$ centuries the region was under the control of the Qarlik, Oghiz and the Samanids. At the enf of the $10^{\text {th }}-11^{\text {th }}$ centuries, the oblast of Shawghar-Qarachuq and its main city were under the power of the Turkic dynasty of the Qarakhanids.

According to information from written sources of the $8^{\text {th }}-11^{\text {th }}$ centuries, it is clear that the main city in the region of Turkestan in that period was Shawghar, which was centered on the ancient settlement of
Tortkul 1-located $8 \mathrm{~km}$ to the north of the city. According to the account of the Arabic geographer of the $10^{\text {th }}$ century Maqdisi/Muqaddasi, "Shawghar is a large city with an extensive fortress, and in it there is a citadel. The congregational mosque is on the edge of the market. It is far (isolated) from the highway. The etymology of the name Shawghar, in the meaning of «black mountain» is of Soghdian origin and corresponds to the ancient Turkic toponym «Qarachuq». (Sharapatuly Sh., 2011)

Shawghar is first encountered under the name Qarajuq in Mahmud Kasghari: "Qarajuq-the name of Farab, is one of the Oghiz cities. The two neighboring historical oblasts Shawghar/Qarachuq and Farab/ Otrar frequently appear in sources under the combined name Tarbad. In the $12^{\text {th }}$ century in the pages of medieval historic and geographic literature, the name «Shaghar»disappears and its Turkic equivalent «Qarachuq» is established. In Kazakh legends it was later known as a city with a large number of gates: «Қырық қақпалы Қарашық» (forty gated Qarashiq).

In the $12^{\text {th }}$ century, the future saint, shaykh Ahmad Yasawi, settled in Yasi, which was situated a short distance from the center of the region, Qarachuq. Archaeological research of the cells of Khoja Ahmad Yasawi shows that they were built in the $12^{\text {th }}$ century. From this time began a new period in the history of the city of Yasi/Turkestan. If Shawghar/Qarachuq was the center of the region in the $8^{\text {th }}-12^{\text {th }}$ centuries, then following this the status of capital passed to Yasi.

Khoja Ahmad Yasawi, over whose grave the mausoleum was built, is considered an extremaly famous Turkic Sufi shaykh, saint and eponymous founder of a Sufi botherhood. Subsequently, his hikmat, in which the basis of the Islamic worldview and the moral decline of society are narrated, received wide diffusion throughout the entire Turkic world.

In the hikmat, in language easily accessible to the understanding, are appeals to kindness, modest contentment, and the condemnation of duplicity, greed and lies. In its poems there is advocated an ascetic form of life and the moral and spiritual perfection of the individual. Its name became known far beyond the limits of Turkestan - in the vast territory of Central Asia, Asia Minor, Azerbayjan, and the Volga region.

The Yasawiya Sufi brotherhood, the eponym of which became Khoja Ahmad, informed the foundation of a number of brotherhoods and expanded Sufic learning through the whole of the Islamic world. Among the peculiarities in the 
learning and practice of the brotherhood may be mentioned the vocal form of the rites - «dhikr-I arr» and the participation of women in Sufi ceremonies. The brotherhood occupies a noticeable place in the history and culture of the Turkic nations in the wide expanse of Eurazia.

According to one version, Khoja Ahmad Yasawi was born in the medieval city of Sayran, which is not far from the modern city of Shimkent - the oblast center of Southern Kazakhstan. According to information from the work Hazinat al-asfiya, Khoja Ahmad received the favorable opinion of shaykh Arslan in his childhood, one of the greatest of the Turkic shaykhs. "According to the instruction of the minister of God Muhammad, may the blessings and grace of Allah be upon him, Bab Arslan gave Khoja Ahmad both a spitiual and physical education and Khoja Ahmad thrived, having been placed in his service» (Urunbayev A. 2002). After the death of Khoja Ahmad there was a funeral in the cemetary of the settlement of Yasi. There are two version of the probable birth and death of the real historical personage, Sufi shaykh Khoja Ahmad Yasawi. Some researchers think that he was born at the beginning of the $12^{\text {th }}$ century and died at the beginning of the $13^{\text {th }}$ while others assert the year of his death to be 562/1166-1167. (Mankovskaya L.YU., 1963)

Sufis represented by A. Yassawi substantiated the idea of personal piety, which they opposed to social norms and Sharia conformism of the Sunnis. Sufism was a more suitable religion for the nomad, as he impressed with his personal attitude to God, his spirit of individualism, and he was well suited to the traditional practices of shamanism and the cult of Tengri. Yassawi developed a practice in which preference was given to individual prayer and contemplation of God through love. He lamented the domination of oppression and poverty in the world, offering a way of humility and acceptance of reality. The path of self-denial and spiritual selfpurification, overcoming life problems based on the individual and not on the correction of society, are more consistent with the spirit of the Turkic nomads of that distant time and the socio-cultural reality of the Medieval East Central Asia.

The attractiveness of the Sufi ideas of Yassawi clearly appears in essence the path of tariqa. The Thinker advised to love life, to live with God, to "die before death comes. 'It means becoming totally wise in this world to join this divinity here on earth.

If you're in love, take the path of love

Reject this world - the example is Adham.
A reasonable man, do not try to suffer for the sake of wealth.

Retribution is waiting On the Day of Judgment, friends.

The lover drank the secrets of wine without knowing himself.

He will not take the sweets of this world into his eyes,

One hundred thousand tips will not enter his mind,

As a flower garden bloomed, and does not know himself, friends

Khoja Ahmed Yassawi says that God is in the heart of man, only you need to find a way to him. (Yassawi A., 2000)

Sufi of A. Yassawi reveals a new aspect of human creativity, when he creates a universal world - numinous reality, the dimension of which is unconditional, spiritual and sublime love for God. Sufism is developing a new way of understanding the numinous reality, which can be realized through a new kind of knowledge - knowledge-experience. The emotional component includes the concept of knowledge of the Sufi, it includes the entire volume of emotional and "existential" experience, his attitude to himself, to other people. It includes all human States, feelings, volitional intentions, memories, i.e. the entire spiritual universe in which people exist. Such a universe is being-consciousness, i.e. it is a world of philosophical reflections, religious searches, feelings and experiences, it is a world of art, a world of relationships with spiritual, sacred entities.

The unique side of Sufi culture is the spiritual world, its emotional component. The universal means of his "presence" is art, his artistic culture, creativity, his faith. Through art - poetry, dance, music, the Sufi directs his emotional experiences into creativity. Through his volitional effort, he turns them into objective, generally significant forms of culture.

Sufism in the person of A. Yassawi is at the forefront of the formation of humanitarian knowledge in the Islamic world of culture. Love, hate, envy, jealousy, fear, pain and other emotional experiences act as universal phenomena, as emotional states, they are filled with meanings, passion through interaction with religious faith, the power and creativity of which lies in the love of God. The phenomenology of Sufism not only represents knowledge-dialogue, knowledge-immersion, knowledge-experience, but also the world of emotional culture. On its basis, the most expressive, ecstatic forms are developed in the form of an altered state of consciousness. Through 
it, one can not only enter into this world of the numinous, discover its reality, but also experience this state of entry, communication and union with the numinous, sacral, and contact the highest and sublime form of the perfect Ideal of Love, the image of a worthy Beloved.

For the Sufi, the numinous world is not only the sacred world, but the spiritual world. Spirituality in the phenomenology of Sufism is revealed through love, which is conceived and experienced as the highest form of love dialogue, resulting in the form of knowledge-experience. Thus, the Sufi phenomenology influenced the formation of such cultural phenomena as a combination of its spiritual forms as philosophy, art, religion, folk mythology. The meanings of a person's being in the world, the human ways of "being present" in him are embodied in them. This is where the original humanitarian culture is found. Suf through phenomenology showed the presence of the semantic field of culture. This was made possible on the basis of phenomenology, through which they were able to show the independence of the spiritual component. It is the presence of this independence of spiritual culture that allowed the Sufis to carry the idea of creativity, in which the most supreme forms of human spiritual takeoff are shown (Mandel B.R., 2006).

For many centuries, Sufism, despite the growing interest in material goods and the desire to push it back to the marginal Islamic culture, has developed and managed to enrich the spiritual heritage of peoples (Kuttykadam S., 2005).

Islam in the early stages tried to implant its value system. In opposition to him, Sufism, through its phenomenology, not only preserved the autochthonous values of non-Arab peoples, but also found a cultural lagoon with which it managed to translate the uniqueness of the spiritual aspect of culture, assimilate Islam and introduce high standards of cultural values into its space.

Developing devotion and sincerity of faith in Islam, Sufism gives it a high spiritual color, perfecting the system of spiritual values, preserving the emotional layer of Islamic culture.

Sufism plays the role of a cultural-psychological factor in preserving ethnic memory and spiritual life, the cultural values of the Iranian-Turkic peoples. In our opinion, it represents such a worldview, and a way of organizing life that only culture performs. Otherwise, he performs a complex mechanism for cultural adaptation to new realities, based on the formation of a new cultural picture of the world. The fulfillment of these cultural functions takes place in the context of a cultural and civilizational shock experienced by both peoples and people. They find in Sufism a new way of cultural and individual identity. This doctrine demonstrates a new cultural mechanism for forming a model of the world, actively defending spirituality as a matrix for the formation of cultural identification in conditions of social instability.

Sufism substantiates the socially active and activity-related attitude to the world, shows the importance of preserving a personal and spirituallyorganized life. He contrasts the new cultural strategy of behavior and communication of material, pragmatically oriented life, for which the acquisition of material goods, the desire to establish power and domination is an indicator of success and happiness. He does not accept a way of life in which the lack of spiritual values is replaced by the acquisition of material goods as a vector of human existence. Sufis propose a new strategy of life, in which the main mode is to hope for God's mercy, aspiration of thought, action, actions towards God, where all human life passes under the gaze of God, is based on love for Him.

$\mathrm{He}$ offers one of the possible options for the formation of such a cultural niche, which favorably created the conditions for adaptation to new socio-political and cultural conditions. Such a niche is the phenomenology of Sufism. Through it, the ideological influence on the formation of religious tolerance, tolerance to foreign cultural traditions, other forms of social life organization is exercised. In the phenomenology of Sufism, there is an accumulation of cultural values, a system for transmitting the tradition of honoring the sacred, and the experience of communicating with the numinous. It presents a unique culture of the intuitive way of comprehending the world.

The ecstatic state of consciousness, developed by Sufism, appears as a side of the traditional society of Orphic culture, which represents the experience of the psychological defense of the ethno-cultural community. In a culturally acceptable form, Sufism presents the experience of resolving the internal conflict between the individual desires of a person and the cultural norms of the Islamic community, thereby helping to reduce the likelihood of psychological dysfunctions in a person's cultural behavior.

Sufism played an important role in preserving the moral and spiritual health of the peoples who, in the course of the aggressive policy of the Arab caliphates, found themselves in a difficult situation-a socio - cultural crisis, which is accompanied by 
the unification of their cultural and social life, the destruction of centuries-old spiritual tradition, way of life, moral values, family, marriage. In the context of cultural shock Sufism not only contributed to the formation of new options for meeting with a foreign culture, but also the search for new cultural mechanisms for the creation and translation of spiritual reality. In the context of cultural shock Sufism offers a new model of religious identity, on the basis of which the process of entering into a new reality takes place. Sufism offers a new cultural and psychological mechanism for the adoption of a new cultural identity, while adapting to her former system of cultural values.

In the course of archaeological research on the mausoleum complex, building consructions were revealed, releated to the first mausoleum of Khoja Ahmad Yasawi, which permit us to precisely define the life of the great shaykh. Technical peculiarities of the consruction and the facing of the remnants of the early mausoleum of the shaykh allowed the art historian L.Yu. Mankovskaya to attribute the time of the building of the first mausoleum of Khoja Ahmad Yasawi to the second half of the $12^{\text {th }}$ century. On the basis of these facts, it may be considered close to a true estimation that the death of Khoja Ahmad Yasawi happened in the year 562/1166-67.

As long ago as 1928, M.Ye. Masson, conducting research on the monument, proposed the presense of the first mausoleum of Khoja Ahmad Yasawi: “...on his grave was built a small mausoleum..." (Masson M.E., 1998.).

It is very possible that five carved, unpainted bricks from the revetment of the main façade, found in 1923 during the restoration of the roof of the mausoleum, belonged to precisely this small building». During the restoration works of 19391941, in the course of clearing the roof, terracotta tiles and bricks, which adorned the more ancient mausoleum above the grave of Khoja Ahmad Yasawi, were recovered among the debric.

In October 1957, during the restoration of the plinth on the western edge of the northern portal, a wallof the first mausoleum of Khoja Ahmad Yasawi was revealed in the western pylon. A fragment of revetment was found - a simulated facing of paired bricks with an arrangement of vertical «bows» (about 1 sq.m), in a checkered pattern, inserted between them. The remnants of these consrutions 2-3 m high walls - were revealed in the course of restoration work in 1975 in the area of the ziyaratkhana.

During renovations in 1994, around 60 fragments of engraved terracotta of various sizes were collected from the roof of the architectural complex of Khoja Ahmad Yasawi, among which were angled and flat plates with dual engraving. Analysis of these facts allowed the archaeologist E.A. Smagulov to make the following conclusion: the first mausoleum of Khoja Ahmad Yasawi, in terms of its decorative characteristics, equaled the most elite and modern monuments of its time. As a whole the décor of the first mausoleum of Khoja Ahmad Yasawi displays a mastery of vegetal-geometric compositions exceeding that of all the distinctive monuments of the second half of the $12^{\text {th }}$ century; (Smagulov E.A., Grigoriev F.P., Itenov A.A., 1998)

\section{Conclusion}

The construction of the mausoleum of Khoja Ahmad Yasawi, an enormous religious complex that contains a mosque, burial chambers, and a madrasa, allowed those devoted to Islam to live a separate life united beneath one roof. Within the structure, there are 34 rooms of various sizes. Standing in line from south to east is a great entrance, a central hall and cauldron room, and burial chamber for saints.

According to M.Ye Masson, after Friday namaz the derviches would perform dhikr and read extracts from the hikmats of Ahmad Yasawi. According to eyewitness accounts of Russian and European travelers, huge numbers of people would gather to admire the dhikr.

The mosque was connected to the central cauldron hall and the library by way of the tiger house corridor.

The text of the Arabic inscriptions of the mausoleum of Kh. In the early Soviet period, M.Ye. Masson studied the history of the mausoleum of Kh. A.A. Ivanov thoroughly examined most of the bronze items from the mausoleum and translated the inscriptions on them into Russian with maximally complete commentary.

B.T. Tuyakbayeva successfully published a special work devoted to the epigraphy of the entire complex. In spite of the wide range of these comleted efforts, these publications had specific failings: for example, in most cases, translations of the inscriptions were not provided with original texts.

Eventually, Kazakhstan took extensive measures concerning the preservation of its national cultural heritage after attaining independence. The Republic of Kazakhstan, being a sovereign state, acceded to the Convention for the Protection of the World Cultural and Natural Heritage of 1994. According to agreements made between Kazakhstan and 
Turkey in 1993-1995, Turkish specialists completed efforts to reinforce the base and foundations of the mausoleum of Koja Ahmad Yasawi. Howeever, for a series of reasons, the horizontal waterproofing of the walls was not accomplished in the manufacture of the pile foundations. In 1995-2000a great effort in the restoration of the mausoleum of Khoja Ahmad Yasawi was carried out by the Turkish company «VakifInsaat»

The first monument, which Kazakhstan entered in the «Preliminary World Heritage List of
Monuments» from the Republic, was the mausoleum of Khoja Ahmad Yasawi. During the $27^{\text {th }}$ session of the General Conference of UNESCO, held from the $30^{\text {th }}$ of June to the 5th of July 2003, the Committee of the World Heritage List of UNESCO. The restorationists of Kazakhstan continue to investigate the condition of the monument, to describe problems appearing as a result of the latest restorations of the buildings, and to develop recommendations to stabilize temperature and humidity conditions in the mausoleum.

\section{References}

Abdurrahman El-Hazini (1995) «Cevahirul-ebrar min emvac-I bihar «Yesevi Menakibnamesi» - Kayseri - pp. 77

Deweese D. (1999) «The politics of Sacred Lineages in 19th-Century Central Azia: Descent Groups Linked to Khwaia Ahmad Yasavi in Shrine Documents and Genealocical Charters» // International Journal of Middle East Studies, - pp. 530.

Jarmuhameduly M. (1999) «Qozha Axmet Yassawi jane Turkistan»-Almaty - 34 b.

Kuttykadam S. (2005) «Ogon i pepel sufizma» // - Almaty. Mysl. - № 6, - 8-16 s.

Mandel B. (2006) «Misticheskoe serdce islama ili Neravnodushniy vzglyad filosofia-kulturologia na sufizm» // Voprosı kulturologii. - № 10,-31-33 s.

Mankovskaya L. (1963). «Issledovanie arhitekturnogo kompleksa-mavzoleya Axmada Yasawi v gorode Turkestane I vopros1 ego restavracii». Avtoreferat dissertacii na soiskanie ucheniy stepeni kandidata iskustvovedeniya. - Tashkent. - $265 \mathrm{~s}$.

Masson M. (1998). «O postroyke mavzoleya Hodzha Axmeda v gorode Turkestane» // v sb.: Zagadki drevnego Turkestana. Almaty, $-158 \mathrm{~s}$.

Prozorov S. (2006). «Islam na territorii byvshey Rossiyskoy imperii: enciklopedicheskiy slovar». - Moskva - $655 \mathrm{~s}$.

Smagulov E., Tuyaqbaev M. (1998). «Turkistannyn ortagasyrlyq tarihy» - Turkistan, - 3-6 b.

Smagulov E., Grugorev F., Itenov A. (1998). Srednevekovaya arheologiya goroda Turkestana. - Turkestan. $-228 \mathrm{~s}$.

Sharapatuly Sh. (2011). M. Qashqaridyn «Turki tilderi sozdiginin» tarihynan // Altaistika jane turkologiya. - №3.

Urunbaev A. (2002) «The letters of khwajaubayd allah ahrar and his associates. Persian text, english translation with notes, introductory». - Leiden, $-472 \mathrm{p}$.

Yassawi A. (2000) «Diyani hikmet» / Perevod na kaz.yaz. Kari K., Kambarbekova G., Ismailzade R. - Tegeran. - 134 xikmetov. 